University of Wollongong

Research Online

Faculty of Engineering and Information

Faculty of Engineering and Information

Sciences - Papers: Part B

Sciences

2019

\title{
Understanding the Self-Sintering Process of BOS Filter Cake for Improving Its Recyclability
}

Raymond Longbottom

University of Wollongong, rayl@uow.edu.au

Brian J. Monaghan

University of Wollongong, monaghan@uow.edu.au

David J. Pinson

BlueScope Steel Limited

Sheng Chew

BlueScope Steel Limited, shengc@uow.edu.au

Follow this and additional works at: https://ro.uow.edu.au/eispapers1

Part of the Engineering Commons, and the Science and Technology Studies Commons

Research Online is the open access institutional repository for the University of Wollongong. For further information contact the UOW Library: research-pubs@uow.edu.au 


\title{
Understanding the Self-Sintering Process of BOS Filter Cake for Improving Its Recyclability
}

\author{
Abstract \\ Basic oxygen steelmaking (BOS) filter cake has been found to undergo a self-sintering process, improving \\ its mechanical properties to allow easier recycling and utilization on plant. The aim of this study was to \\ gain an understanding of the self-sintering of the BOS filter cake in terms of what reactions occurred, and \\ how strength developed in the filter cake during self-sintering. The approach used was to characterize \\ samples before reaction, and to measure the reactivity of the BOS filter cake during heating in air. Reacted \\ samples were characterized and compared to self-sintered samples from the plant. The BOS filter cake \\ consisted of very fine particles $(200-500 \mathrm{~nm})$ of metallic iron and wüstite. Upon heating in air from 100 to \\ $1000{ }^{\circ} \mathrm{C}$, the BOS filter cake underwent a sequence of drying, oxidation, and calcination events. The \\ primary reactions in self-sintering were found to be the oxidation of metallic iron and wüstite to hematite \\ and zinc ferrite, beginning at approximately $120^{\circ} \mathrm{C}$ and were largely completed by $500-600{ }^{\circ} \mathrm{C}$. These \\ exothermic oxidation reactions at low temperatures were likely driven by the very fine particle size, and \\ provided the energy required to heat the stockpiles and drive self-sintering. The strength required for \\ recycling the BOS filter cake appeared to result from a network of particle-particle bonds that formed \\ between the very fine iron oxide particles in the matrix during oxidation at elevated temperatures. \\ Temperatures between 600 and $800{ }^{\circ} \mathrm{C}$ under oxidizing conditions are likely sufficient to form adequately \\ strong material for transport and recycling in the BOS.

\section{Disciplines} \\ Engineering | Science and Technology Studies

\section{Publication Details} \\ Longbottom, R. J., Monaghan, B. J., Pinson, D. J. \& Chew, S. J. (2019). Understanding the Self-Sintering \\ Process of BOS Filter Cake for Improving Its Recyclability. Journal of Sustainable Metallurgy, 5 (3), \\ 429-441.
}




\section{Understanding the self-sintering process of BOS filter cake for improving its recyclability}

Raymond J. Longbottom, School of Mechanical, Materials, Mechatronic and Biomedical Engineering and ARC Research Hub for Australian Steel Manufacturing, University of Wollongong, Wollongong, NSW 2522, Australia. Orcid: 0000-0003-1033-7195. Ph: +61 24221 4502. Email: rayl@uow.edu.au

Brian J. Monaghan, School of Mechanical, Materials, Mechatronic and Biomedical Engineering and ARC Research Hub for Australian Steel Manufacturing, University of Wollongong, Wollongong, NSW 2522, Australia. Orcid: 0000-0002-6341-3588.

David J. Pinson, BlueScope Coke and Ironmaking Technology, Port Kembla, NSW 2505, Australia. Sheng J. Chew, BlueScope Coke and Ironmaking Technology, Port Kembla, NSW 2505, Australia. 


\begin{abstract}
Basic oxygen steelmaking (BOS) filter cake has been found to undergo a self-sintering process, improving its mechanical properties to allow easier recycling and utilisation on plant. The aim of this study was to gain an understanding of the self-sintering of the BOS filter cake in terms of what reactions occurred, and how strength developed in the filter cake during self-sintering. The approach used was to characterise samples before reaction, and to measure the reactivity of the BOS filter cake during heating in air. Reacted samples were characterised and compared to self-sintered samples from the plant. The BOS filter cake consisted of very fine particles (200-500 $\mathrm{nm}$ ) of metallic iron and wüstite. Upon heating in air from 100 to $1000^{\circ} \mathrm{C}$, the BOS filter cake underwent a sequence of drying, oxidation and calcination events. The primary reactions in self-sintering were found to be the oxidation of metallic iron and wüstite to hematite and zinc ferrite, beginning at approximately $120^{\circ} \mathrm{C}$ and largely complete by $500-600^{\circ} \mathrm{C}$. These exothermic oxidation reactions at low temperatures were likely driven by the very fine particle size, and provided the energy required to heat the stockpiles and drive self-sintering. The strength required for recycling the BOS filter cake appeared to result from a network of particle-particle bonds that formed between the very fine iron oxide particles in the matrix during oxidation at elevated temperatures. Temperatures between $600-800^{\circ} \mathrm{C}$ under oxidising conditions are likely sufficient to form adequately strong material for transport and recycling in the BOS.
\end{abstract}

Keywords: BOS filter cake; recycling; sintering; by-products;

\title{
Acknowledgements
}

Funding from the Australian Research Council Industrial Transformation Research Hubs Scheme (Project Number IH130100017) is gratefully acknowledged. This research used equipment funded by Australian Research Council grant LE0882813 and located at the UOW Electron Microscopy Centre. 


\section{Introduction}

Future environmental and economic sustainability of the steel industry will at least in part be achieved by increased on-plant recycling [1,2]. An area of particular interest and opportunity for recycling improvements relates to the dust generated during the basic oxygen steelmaking (BOS) process. In the BOS, oxygen is blown at supersonic velocities to decarburise the steel. This blowing results in significant amounts of gas and dust being generated. The dust, made up of steel and slag droplets, as well as flux fines, contains valuable elements such as iron and calcium [1-4]. It is desirable to reuse this dust in the BOS process and elsewhere to reclaim these elements.

Unfortunately, the BOS dust also contains significant quantities of zinc that limits its use in the BOS process or elsewhere in an integrated steelplant (such as in the blast furnace) [4,5]. In the BOS process, temperatures well in excess of $1600^{\circ} \mathrm{C}$ are readily realised. These high temperatures cause volatilization of the tramp elements of a BOS charge, such as zinc, to the gas phase. As the gas phase is cooled in the extraction process, these volatilised metals can condense as separate particles or onto existing dust particles. Any recycling of the dust back into the steelmaking route, and in particular the BOS vessel, can therefore result in a recirculating and increasing zinc load.

However, the zinc content of the BOS dust can also be increased by alternative recycling processes to levels between zinc ore and zinc concentrates. Through recycling it may be possible to create a product that may be used as an input for a zinc recovery process, through either a pyro- or hydrometallurgical route. In this case, the high iron content and form of the zinc (possibly zinc ferrite) may be a concern for zinc producers $[6,7,8]$. Hence, knowledge of the form in which the iron and zinc are found within the BOS dust is crucial in understanding how to best recycle the dust or how best to process it for recycling $[2,4,5,9,10]$.

BOS dust is often removed from the off-gas using a wet scrubbing process, resulting in a slurry that is usually dewatered to produce a low moisture filter cake that is stockpiled for future recycling. Experience has shown that this filter cake has a tendency to self-sinter $[11,12,13]$, which is likely a result of exothermic oxidation reactions.

This self-sintering behaviour of BOS filter cake in stockpiles helps to enhance its recyclability as it improves the filter cake handling/transport properties, with higher strength and larger particle size, when compared to the original dust. The larger particle size self-sintered filter cake $(>4 \mathrm{~mm})$ is recycled directly into the BOS as a coolant and source of iron. Smaller size filter cake $(<4 \mathrm{~mm})$ may be recycled elsewhere, usually at a lower rate and commonly via ore sintering.

The recycling rate of the $<4 \mathrm{~mm}$ material is often limited by the effects of zinc (or other elements) on the processes they may be recycled to. For instance, recycling too much zinc through the sinter plant may lead to process (and OHS) problems in the blast furnace [4].

If the self-sintering agglomeration of the BOS filter cake in the stockpiles can be enhanced or optimised to produce stronger filter cake, this will likely result in more $>4 \mathrm{~mm}$ material. This will allow greater amounts to be recycled to the BOS, improve the environmental performance of the plant and lower production costs through the reclaiming of the valuable $\mathrm{Fe}$ and $\mathrm{Ca}$ units in the filter cake. 
At this point the mechanistic details of the self-sintering and an improved understanding of the oxidation and selfsintering behaviour of the BOS filter cake are required if it is to be optimised. One difficulty in achieving this goal is the well-known issue of the high variability of steel plant by-products $[1,2,9,10]$. In the case of BOS dust, the composition, phase content and particle size can change from heat to heat, depending on the target steel grade and charge materials (hot metal and scrap composition), as well as within a single heat, depending on the blowing conditions and any additions made (fluxes and coolants). This variability in material makes both a thorough characterisation of the BOS filter cake and acknowledgment of the limitations of the characterisation important. The latter is often neglected in the literature $[2,14,15,16]$.

The main objective of this study was to help improve the utilisation of the BOS filter cake by on-plant recycling to the BOS by improving the understanding of the self-sintering process. The specific aims were:

1. To characterise the BOS filter cake with a view to identifying what reactions occur during the selfsintering process; and

2. Identify what conditions are required during self-sintering for the formation of bonds which lead to increased strength within the BOS filter cake.

To achieve these aims, unreacted, freshly produced BOS filter cake from the BlueScope steelworks has been characterised by several techniques, including scanning electron microscopy (SEM), X-ray diffraction (XRD), thermo-gravimetric analysis (TGA) and differential scanning calorimetry (DSC). Self-sintered BOS filter cake from the plant stockpiles was also characterised by XRD and SEM, and compared to samples reacted with air during heating in a TGA to help assess what changes and reactions occur during the self-sintering process.

\section{Experimental}

The approach used for this study was to start with characterisation of both self-sintered and fresh, unreacted BOS filter cake, using XRD and SEM. The reaction of the BOS filter cake with air was then studied non-isothermally during heating to $1000^{\circ} \mathrm{C}$, in both a large sample TGA and in a small sample TGA-DSC apparatus. Selected samples heated in the large sample TGA were fast cooled from specific temperatures during the heating programme. These samples were characterised to examine the effect of temperature on the phase distribution, the microstructure and the extent of bond formation. The microstructures and bonding formed within these fast cooled samples were compared against self-sintered samples.

\section{Materials}

Both fresh, unreacted BOS filter cake and self-sintered filter cake samples were taken from the BlueScope Port Kembla steelworks. Two types of self-sintered samples from the plant stockpiles were collected, one with and one without adequate strength for recycling. The composition, as measured by XRF, of fresh, unreacted BOS filter cake is given in Table 1. It should be noted that some variation in the composition of the samples was found, and the effect of the variation on reactivity will be discussed later.

Table 1. Composition of fresh, unreacted BOS filter cake, as measured by XRF in mass\%. The variability between samples is indicated by one standard deviation. 


\begin{tabular}{|c|c|c|c|c|c|c|c|c|c|c|c|}
\hline $\mathrm{MgO}$ & $\mathrm{Al}_{2} \mathrm{O}_{3}$ & $\mathrm{SiO}_{2}$ & $\mathrm{P}_{2} \mathrm{O}_{5}$ & $\mathrm{SO}_{3}$ & $\mathrm{~K}_{2} \mathrm{O}$ & $\mathrm{CaO}$ & $\mathrm{TiO}_{2}$ & $\mathrm{MnO}$ & $\mathrm{Fe}_{2} \mathrm{O}_{3}$ & $\mathrm{ZnO}$ & moisture \\
\hline $1.9 \pm 0.1$ & $<0.5$ & $2.3 \pm 0.8$ & $<0.5$ & $<0.5$ & $<0.5$ & $4.7 \pm 0.1$ & 0.0 & $0.7 \pm 0.03$ & $72.7 \pm 2.1$ & $16.7 \pm 2.9$ & $15.4 \pm 0.5$ \\
\hline
\end{tabular}

\section{Characterisation}

Cross-sections of samples were examined using scanning electron microscopy (SEM) with energy dispersive spectroscopy (EDS) for elemental analysis. The mounted samples were sectioned and then ground and polished to a $1 \mu \mathrm{m}$ diamond finish before carbon coating. High resolution microscopy was carried out using a FEGSEM, a JEOL JSM-7001F, which was equipped with an Oxford Instruments $80 \mathrm{~mm}^{2}$ EDS detector.

Samples for XRD were prepared by hand grinding using a mortar and pestle. XRD analysis of the BOS filter cake was carried out using a GBC-MMA diffractometer. $\mathrm{Cu}-\mathrm{K} \alpha$ radiation was used, with the $\mathrm{X}$-ray tube set to $1 \mathrm{~kW}$ of power ( $35 \mathrm{kV}$ and $28.6 \mathrm{~mA}$ ), with a step size of $0.02^{\circ}$ and a scan rate of $1 \%$ min over the $2 \theta$ range from $20-80^{\circ}$. For simple peak identification and phase analysis, the diffraction patterns were analysed using the Traces ( $\mathrm{v} 6.0$ ) software. The nature of these samples made fully quantitative analysis difficult and hence was not pursued here.

\section{Large sample TGA}

A large sample TGA system, as given in [11-13], was used to measure weight change during reaction of the BOS filter cake with air while heating to $1000^{\circ} \mathrm{C}$. A sample of fresh, unreacted BOS filter cake with a nominal mass of $20 \mathrm{~g}$ (typically a single "biscuit") was placed in an alumina crucible hung from the balance. To ensure good contact between gas and sample, twelve $8 \mathrm{~mm}$ holes were made around the bottom circumference of the crucible.

Samples were initially held at $100^{\circ} \mathrm{C}$ for 70 minutes in Ar. This holding time was determined from initial testing where it was found that the sample weight did not change more than $0.01 \mathrm{~g}$ in 15 minutes after 50 minutes. The system was then heated at $10^{\circ} \mathrm{C} / \mathrm{min}$ to $1000^{\circ} \mathrm{C}$ under air flowing at $1 \mathrm{~L} / \mathrm{min}$. It was held at $1000^{\circ} \mathrm{C}$ in the flowing air for a further 30 minutes before cooling under Ar. Moisture and $\mathrm{CO}_{2}$ were removed from the air and $\mathrm{Ar}$ by passing them through drierite and ascarite prior to entering the furnace. The Ar was further cleaned by passing it through Cu turnings at $300^{\circ} \mathrm{C}$.

The sample mass was logged every second during heating. The TGA data were converted to a dimensionless fractional weight change (FWC, as calculated from Eq. 1) to allow comparison between samples.

$$
\mathrm{FWC}=\left(\frac{\mathrm{W}_{\mathrm{t}}-\mathrm{W}_{\mathrm{o}}}{\mathrm{W}_{\mathrm{o}}}\right)
$$

where $\mathrm{W}_{\mathrm{o}}$ and $\mathrm{W}_{\mathrm{t}}$ are the initial mass and the mass of a sample at time $\mathrm{t}$, respectively in grams.

\section{Fast cooled samples}

To aid identification of what species/phases were reacting within the BOS filter cake during oxidation, samples were fast cooled at different stages during the heating in air. Specifically, samples were rapidly cooled from $400^{\circ} \mathrm{C}, 600^{\circ} \mathrm{C}, 800^{\circ} \mathrm{C}$ and $1000^{\circ} \mathrm{C}$. These temperatures were chosen to investigate specific features in the TGA or TGA-DSC curves. Samples were fast cooled by lifting out of the hot zone of the furnace by $60 \mathrm{~cm}$ under a high 
Ar (5 L/min) flow rate. The fast cooled samples could be handled and removed from the top of the furnace after $\sim 2$ minutes.

\section{TGA-DSC testing}

The reactivity of the BOS filter cake was also examined using TGA-DSC testing, using a Netzsch STA449 F5 Jupiter. Samples of fresh BOS filter cake were heated at $5^{\circ} \mathrm{C} / \mathrm{min}, 10^{\circ} \mathrm{C} / \mathrm{min}$ and $20^{\circ} \mathrm{C} / \mathrm{min}$ to $1000^{\circ} \mathrm{C}$ under air flowing at $120 \mathrm{~mL} / \mathrm{min}$. Different heating rates were used to examine any possible changes in the temperatures of features that occurred in the weight change and DSC curves. The measured data were analysed using the Netzsch Proteus Analysis software version 6.1. The sample size was a nominal $100 \mathrm{mg}$, and the samples were contained within platinum-rhodium crucibles with a thin alumina liner and a platinum-rhodium lid. No drying step (as carried out for the large sample TGA) was used in these tests as the smaller sample size used in the TGA-DSC allowed the samples to dry quickly enough to maintain separation between the drying and low temperature oxidation stages.

\section{Results and Discussion}

The main goal of this study was to develop an understanding of the changes that occur in the BOS filter cake during self-sintering. As such, the first step was to characterise it in both the fresh, unreacted and self-sintered states. The bonding within two self-sintered samples was examined to ascertain the differences. One self-sintered sample was strong enough to be recycled through the BOS, while the other was too weak for recycling. The reactivity of the fresh BOS filter cake samples during heating in air was then measured and the reactions that occurred were then analysed through a variety of techniques. These included post experimental characterisation, thermodynamic analysis and measurement of the enthalpy of reaction.

\section{Characterisation of unreacted and self-sintered BOS filter cake}

The phases present within the plant BOS filter cake samples were analysed by XRD. Several samples were analysed for each type of BOS filter cake, with typical patterns given in Figure 1. The unreacted BOS filter cake contained a number of iron bearing phases, zinc oxide and fluxes. The predominant iron bearing phases were wüstite and metallic iron. It was difficult to differentiate between magnetite and zinc ferrite (or a solution of both) by XRD, caused by the similar crystal structure and lattice spacing for the two phases. There was some variation in composition between samples of the unreacted material. However, this variation was not extensively studied. There was little variation in the total amount of iron and iron oxides in the unreacted BOS filter cake samples when characterised by XRF. On the other hand, when analysed by XRD, a variation between samples in the ratio of wüstite to metallic iron peaks was noted. 


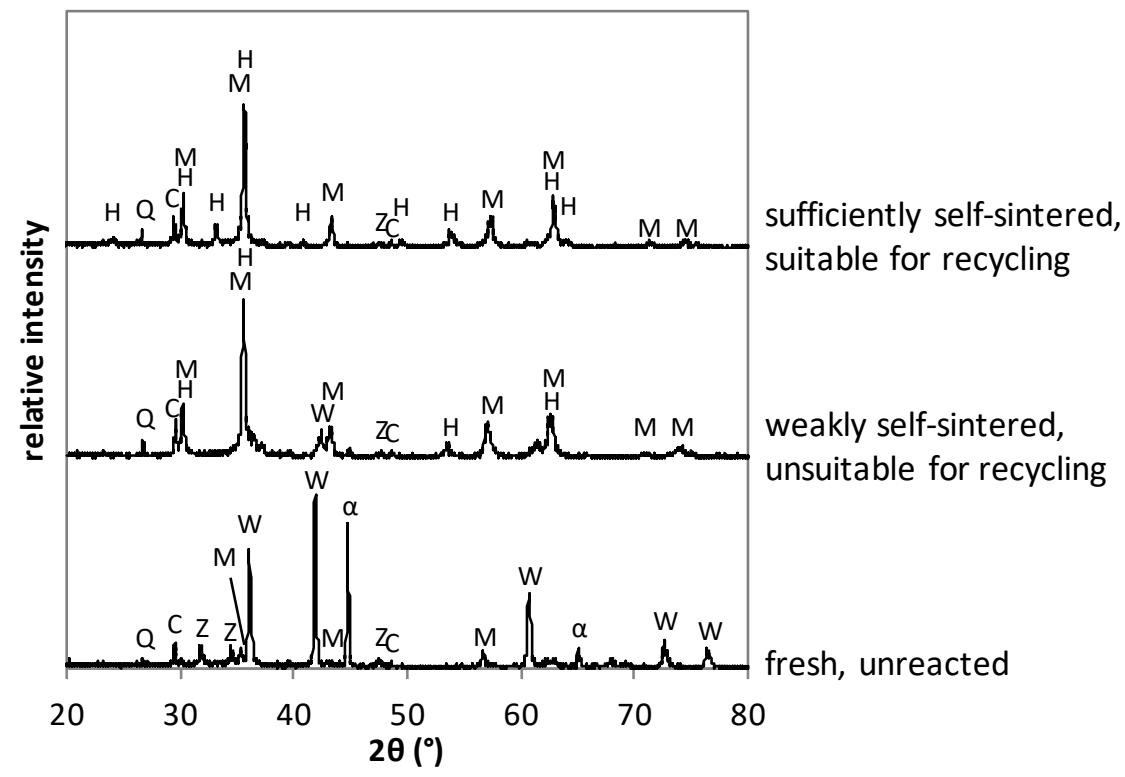

Figure 1. XRD patterns of samples of BOS filter cake collected from industry. Phase key: $\alpha$ - ferrite; W - wüstite; M - magnetite-zinc ferrite (could be either or a solid solution of the two); $\mathrm{H}$ - hematite; C - calcite; Q - quartz; $\mathrm{Z}$ - zincite.

From low magnification micrographs (Figure 2(a)), it can be seen that the unreacted BOS filter cake consists of a few larger particles in a fine matrix. At high magnifications (Figure 2(b)), the matrix could be seen to consist of an agglomeration of sub-micron individual, round particles, with the majority being in the size range 200-500 nm. The larger particles were either spherical iron-rich (metallic or oxide) particles in the range 5-50 $\mu \mathrm{m}$ or more irregularly shaped flux particles in the range 5-100 $\mu \mathrm{m}$. Particles that were likely relicts of limestone (Ca-rich) and dolomite (Mg-rich) were identified through EDS.

Two types of self-sintered BOS filter cake were characterised, one which was weakly self-sintered $(<4 \mathrm{~mm}$, unsuitable for recycling to the BOS) and one which was strongly self-sintered ( $>4 \mathrm{~mm}$, suitable for recycling to the BOS). By XRD, it was difficult to distinguish between the weakly and sufficiently self-sintered BOS filter cake. Several samples of both types of self-sintered BOS filter cake were analysed, and were found to contain mainly magnetite (or zinc ferrite or a solution of the two) and hematite. At low magnifications (Figure 3(a) and (c)), the microstructures of the self-sintered samples appeared similar to the unreacted material. At higher magnifications (Figure 3(b) and (d)), differences between the two samples within the fine iron oxide particles in the matrix of the BOS filter cake were observed. In the weakly self-sintered sample, there was little to no bonding between the particles evident in the matrix. However, in the sufficiently self-sintered sample, the bonding appeared quite developed. The bonding in the reacted filter cake samples was primarily due to particle-particle bonds forming between the fine iron oxide particles. These particle-particle bonds were evidenced by the formation of small (1-2 particles wide and several particles in length) bonded entities within the matrix of the BOS filter cake. 


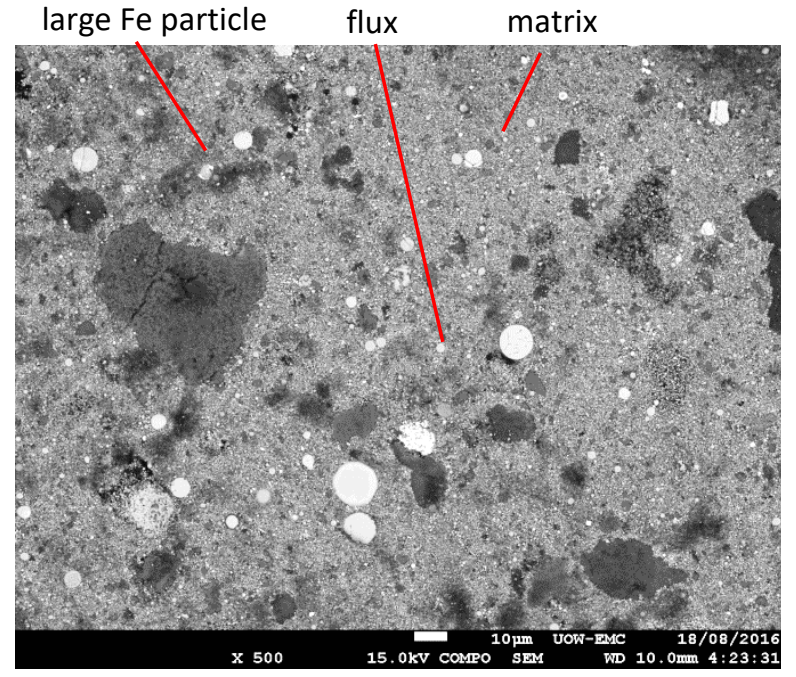

(a)

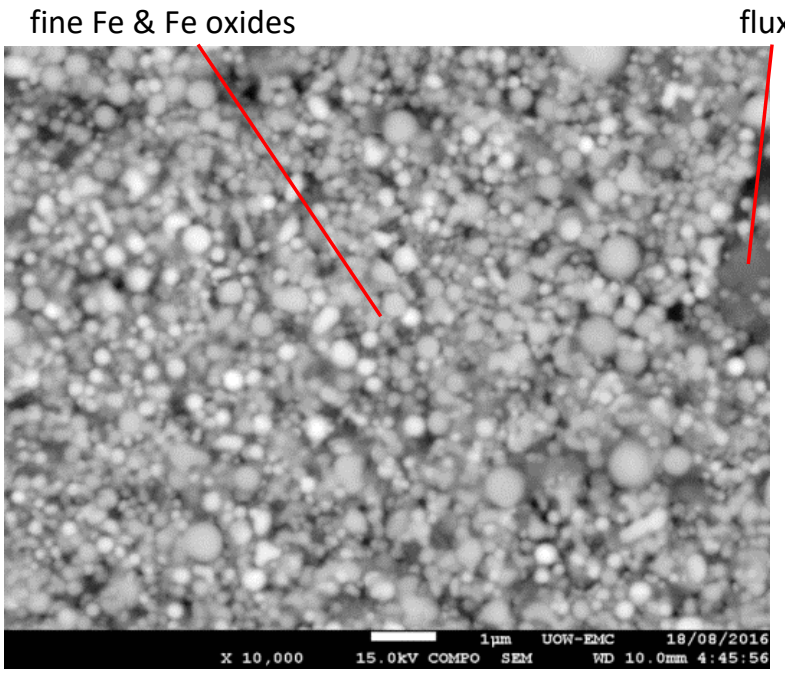

(b)

Figure 2. Micrographs of the unreacted BOS filter cake sample. (a) Low magnification back scattered electron images, the scale bar is $10 \mu \mathrm{m}$; and (b) High magnification back scattered electron images, the scale bar is $1 \mu \mathrm{m}$. 


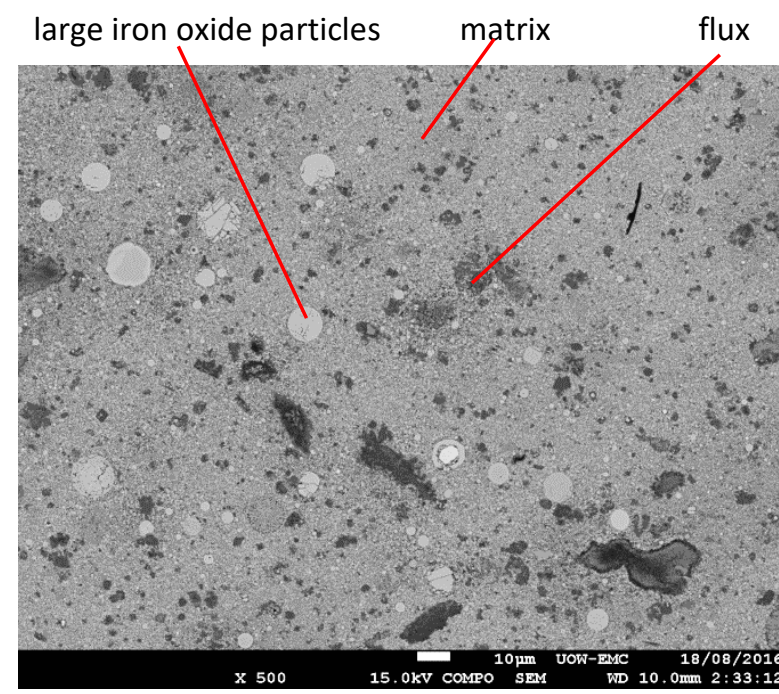

(a)

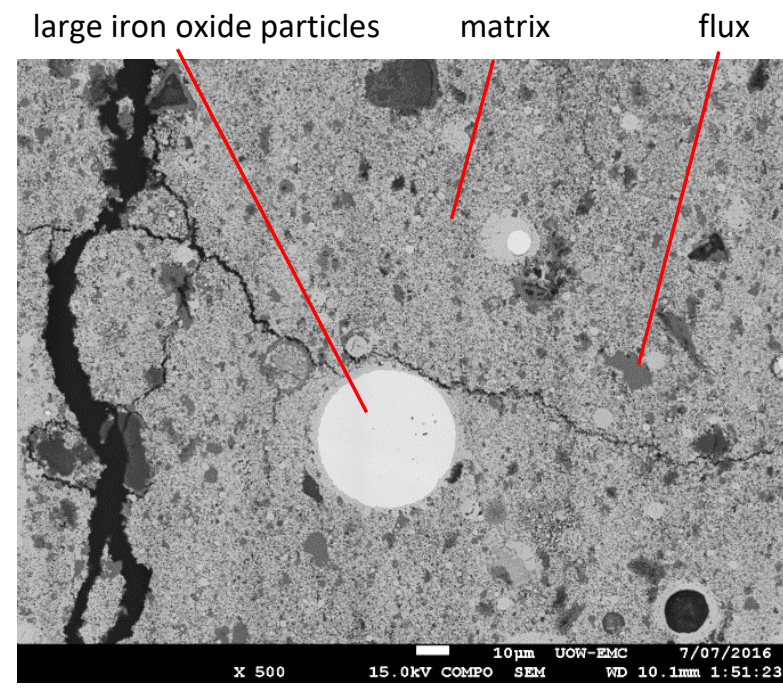

(c)

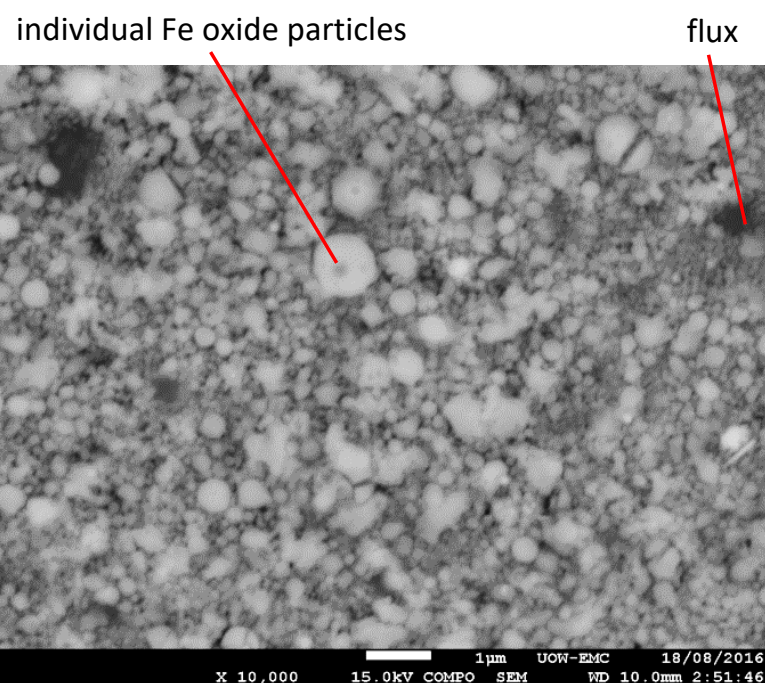

(b)

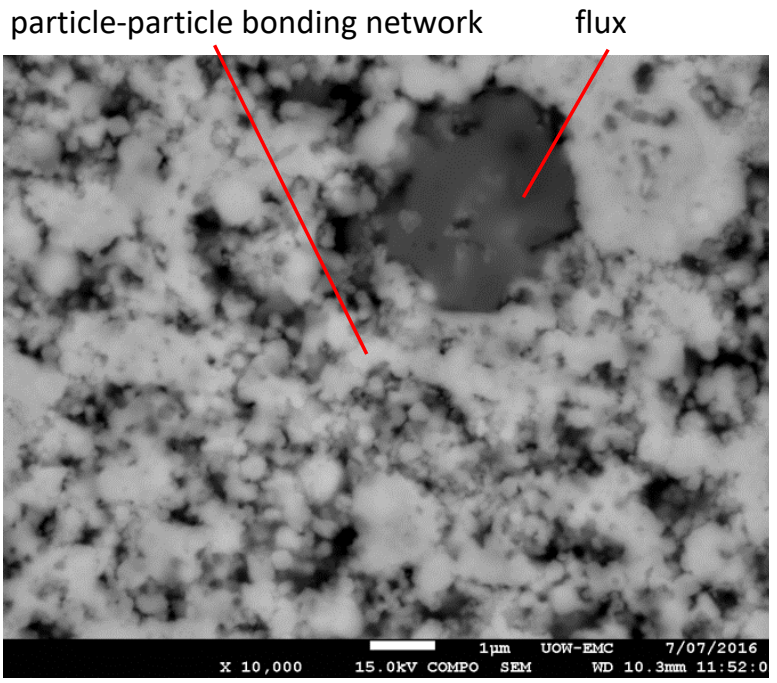

(d)

Figure 3. High magnification SEM images of self-sintered BOS filter cake samples. Self-sintered BOS filter cake that is weakly self-sintered and unsuitable for recycling at (a) low magnification (scale bar $10 \mu \mathrm{m}$ ); and (b) high magnification (scale bar $1 \mu \mathrm{m}$ ). Strongly self-sintered BOS filter cake that is adequately bonded and is suitable for recycling at (c) low magnification (scale bar $10 \mu \mathrm{m}$ ); and (d) high magnification (scale bar $1 \mu \mathrm{m}$ ).

\section{Reactivity of BOS filter cake}

Reactivity testing of the BOS filter cake was carried out to develop an understanding of the processes that might drive the self-sintering in the stockpiles. Large sample TGA tests were conducted on a single piece of unreacted BOS filter cake. In these tests, the samples were initially dried by heating in $\mathrm{Ar}$ to $100^{\circ} \mathrm{C}$ and then holding at this temperature for 70 minutes. While not completely removing moisture from the samples, this drying step was carried out to establish a common starting point for the test with regard to sample moisture. The dried sample was then heated in air at $10^{\circ} \mathrm{C} / \mathrm{min}$ to $1000^{\circ} \mathrm{C}$. Many large sample TGA experiments were conducted to determine the repeatability of the test. Three typical weight change curves from using the large scale TGA are given in Figure 4. These plots show the surprisingly high repeatability of the large scale TGA measurements. Figure 4 was used 
to help identify the characteristic temperature-reaction features occurring during the heating of the BOS filter cake in air.

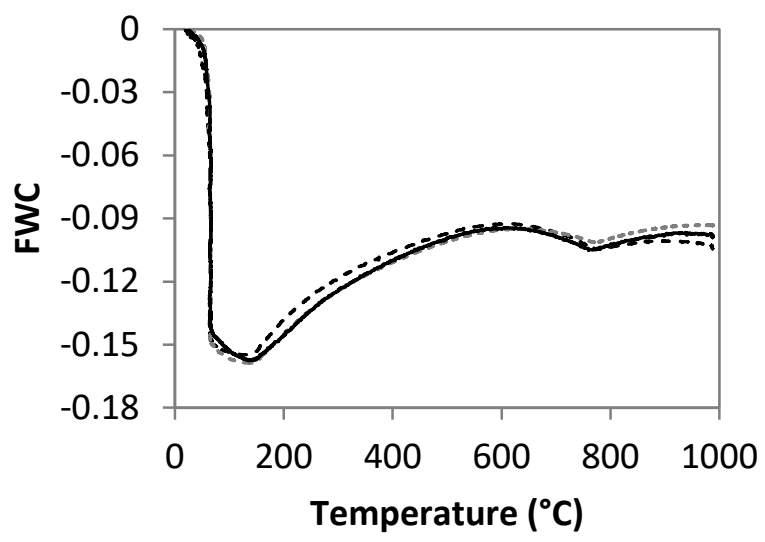

Figure 4. Three typical reactivity measurements for fresh BOS filter cake heated to $1000^{\circ} \mathrm{C}$ in air at $10^{\circ} \mathrm{C} / \mathrm{min}$ in the large sample TGA.

TGA-DSC testing used smaller samples. Typical weight change and DSC curves for heating a nominal $100 \mathrm{mg}$ sample at $10^{\circ} / \mathrm{min}$ to $1000^{\circ} \mathrm{C}$ in air are given in Figure 5. The weight change curves from the TGA-DSC were similar to those of the large sample TGA, with the weight change features in the TGA-DSC occurring at lower temperatures and over smaller temperature ranges when compared to the large sample TGA. This might be expected to occur with the much smaller samples used in the TGA-DSC technique. The use of smaller samples minimised temperature gradients within the sample and any possible mass transfer effects that might be occurring in the large sample TGA, as well as removing the necessity for a drying step in the program. In general, and from a temperature perspective, the exo- or endothermic features in the DSC curves align and were consistent with features observed in the FWC curve.

Different heating rates were used in the TGA-DSC to determine if there was any effect on the temperatures of the different weight change or energy release events. There was a small change in peak positions with heating rate, especially noticeable for the sharp oxidation peak shown in Figure 5(b) in the section labelled Stage 2. This peak changed from $415^{\circ} \mathrm{C}$ at $5^{\circ} \mathrm{C} / \mathrm{min}$ to $436^{\circ} \mathrm{C}$ at $20^{\circ} \mathrm{C} / \mathrm{min}$. However, this change in the peak position was largely expected, and likely did not indicate a change in the reaction occurring or its mechanism. 


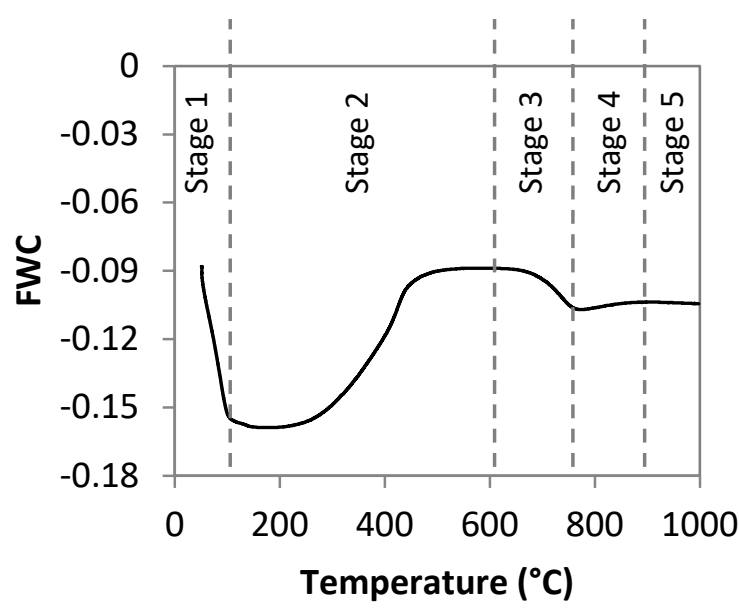

(a)

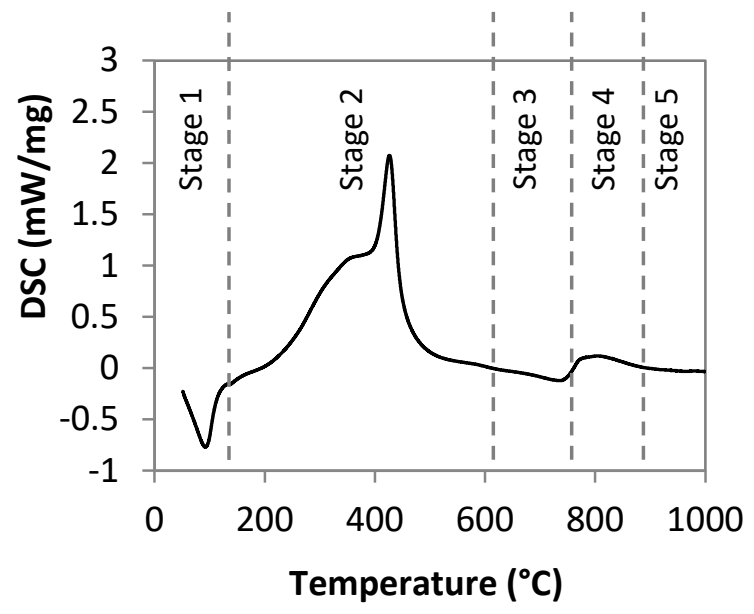

(b)

Figure 5. TGA-DSC results for fresh BOS filter cake heated to $1000^{\circ} \mathrm{C}$ in air. (a) Weight change curve; and (b) DSC curve for a sample heated at $10^{\circ} \mathrm{C} / \mathrm{min}$ (exothermic is positive).

From the similar behaviour of the BOS filter cake in both the large sample TGA and the smaller sample TGADSC, a characteristic behaviour of the BOS filter cake during heating in air was found. This characteristic behaviour is likely that of the BOS filter cake during the self-sintering process. Based on historical bulk composition analysis and the literature [1,5,10], it was expected that the BOS filter cake would be quite variable in both its content and behaviour. Variation in composition between samples of the unreacted material was found, but this appeared to have little effect on the filter cake oxidation behaviour. The unreacted BOS filter cake was comprised mainly of varying proportions of metallic iron and wüstite, it is likely that the presence of these phases in the BOS filter cake, and not their precise proportions, is responsible for the characteristic behaviour. The very fine nature of particles within the unreacted BOS filter cake also likely played a role in determining the characteristic behaviour. The low temperature reactivity was likely to be primarily due to the very fine particle size of the wüstite and metallic iron in the matrix. Fine particles of metallic iron and wüstite would be expected to have high reactivity. As these fine particles comprise the majority of the BOS filter cake, they may be expected to dominate the observed behaviour.

The characteristic behaviour of the BOS filter cake during heating in air was a complex, multi-stage process. The characteristic behaviour was separated into five stages, as indicated in Figure 5, which are described below. The methodologies used to determine which reactions occurred in each stage are also given below.

Stage 1.

Drying of the sample at $\mathrm{T}<\sim 120^{\circ} \mathrm{C}$. This was observed by a decrease in the sample weight and an endothermic peak in the DSC curve. The BOS filter cake contains approximately 15 mass\% moisture, which corresponds well with the weight change recorded in the large sample TGA. Evaporation of moisture is endothermic [17]. The temperature range also matches well with the boiling point of water $\left(100^{\circ} \mathrm{C}\right)$. Hence, this stage was identified as removal of free moisture from the BOS filter cake. 
Stage 2.

Oxidation of the initial metallic iron and wüstite mixture to hematite and zinc ferrite, at $\sim 120-130^{\circ} \mathrm{C}<\mathrm{T}<\sim 600^{\circ} \mathrm{C}$. This was associated with an increase in the weight of the sample, and a large exothermic peak. It appeared that the oxidation of the metallic iron and wüstite did not occur until after the water has been removed from the sample, making it likely that the moisture level of the BOS filter cake is an important parameter in the self-sintering of the BOS filter cake. This observation is supported by similar observations made on-plant for the stockpiled BOS filter cake. At this point it is not clear whether this is a particular characteristic of the BOS filer cake studied, or for all BOS dust, sludge and filter cake from other steel plants.

The weight increase and the exothermic peak for Stage 2 were by far the largest of any of the five stages. Hence, this stage represents both the main oxidation stage and likely main energy source for self-sintering. Understanding what is occurring during Stage 2 is vital for understanding the self-sintering process and improving the recyclability of the BOS filter cake.

Several reactions (Equations 2-9) have been proposed based on the known starting phases and their proportions, and their expected behaviour under oxidising conditions. The reactions given in Equations 2-9 represent overall reactions from initial material to final products, and do not represent a reaction mechanism.

$$
\begin{aligned}
& \mathrm{Fe}_{(\mathrm{s})}+3 / 4 \mathrm{O}_{2(\mathrm{~g})}=1 / 2 \mathrm{Fe}_{2} \mathrm{O}_{3(\mathrm{~s})} \\
& \mathrm{FeO}_{(\mathrm{s})}+\mathrm{O}_{2(\mathrm{~g})}=1 / 2 \mathrm{Fe}_{2} \mathrm{O}_{3(\mathrm{~s})} \\
& \mathrm{Fe}_{(\mathrm{s})}+2 / 3 / 3 \mathrm{O}_{2(\mathrm{~g})}=1 / 3 \mathrm{Fe}_{3} \mathrm{O}_{4(\mathrm{~s})} \\
& \mathrm{FeO}_{(\mathrm{s})}+1 / 6 \mathrm{O}_{2(\mathrm{~g})}=1 / 3 \mathrm{Fe}_{3} \mathrm{O}_{4(\mathrm{~s})} \\
& \mathrm{Fe}_{2} \mathrm{O}_{3}+\mathrm{ZnO}_{(\mathrm{s})}=\mathrm{ZnFe}_{2} \mathrm{O}_{4(\mathrm{~s})} \\
& 2 / 3 \mathrm{Fe}_{3} \mathrm{O}_{4(\mathrm{~s})}+1 / 6 \mathrm{O}_{2}+\mathrm{ZnO}_{(\mathrm{s})}=\mathrm{ZnFe}_{2} \mathrm{O}_{4(\mathrm{~s})} \\
& \mathrm{Fe}_{(\mathrm{s})}+1 / 2 \mathrm{O}_{2(\mathrm{~g})}=\mathrm{FeO}_{(\mathrm{s})} \\
& 2 \mathrm{FeO}_{(\mathrm{s})}+1 / 2 \mathrm{O}_{2}+\mathrm{ZnO}_{(\mathrm{s})}=\mathrm{ZnFe}_{2} \mathrm{O}_{4(\mathrm{~s})}
\end{aligned}
$$

The reactions given in Equations 2-9 were grouped into three different possible reaction schemes that were considered for this stage, as shown in Table 2. These reactions and schemes were proposed based on the known reactive phases within the unreacted $\mathrm{BOS}$ filter cake (metallic $\mathrm{Fe}, \mathrm{FeO}$ and $\mathrm{ZnO}$ ) and what reactions involving these phases are likely to be possible under oxidising conditions. The reaction of $\mathrm{ZnO}$ with the iron oxides to form $\mathrm{ZnFe}_{2} \mathrm{O}_{4}$ in each scheme were included due to the presence of zinc ferrite in the oxidised plant samples. Each of the schemes was considered against three criteria, which were:

1. Thermodynamic modelling of the Fe- $\mathrm{Zn}-\mathrm{O}_{2}$ system using FactSage;

2. Consideration of the phases present in the sample before and after reaction; and

3. Comparison between measured and expected enthalpies of reaction. 
Table 2. Proposed reaction schemes for stage 2 of the characteristic BOS filter cake behaviour during heating.

\begin{tabular}{|c|c|}
\hline Reaction Scheme & Equations \\
\hline 1 & $\begin{array}{l}\mathrm{Fe}_{(\mathrm{s})}+3 / 4 \mathrm{O}_{2(\mathrm{~g})}=1 / 2 \mathrm{Fe}_{2} \mathrm{O}_{3(\mathrm{~s})} \\
\mathrm{FeO}_{(\mathrm{s})}+\mathrm{O}_{2(\mathrm{~g})}=1 / 2 \mathrm{Fe}_{2} \mathrm{O}_{3(\mathrm{~s})} \\
\mathrm{Fe}_{2} \mathrm{O}_{3}+\mathrm{ZnO}_{(\mathrm{s})}=\mathrm{ZnFe}_{2} \mathrm{O}_{4(\mathrm{~s})}\end{array}$ \\
\hline 2 & $\begin{array}{l}\mathrm{Fe}(\mathrm{s})+2 / 3 \mathrm{O}_{2(\mathrm{~g})}=1 / 3 \mathrm{Fe}_{3} \mathrm{O}_{4(\mathrm{~s})} \\
\mathrm{FeO}_{(\mathrm{s})}+1 / 6 \mathrm{O}_{2(\mathrm{~g})}=1 / 3 \mathrm{Fe}_{3} \mathrm{O}_{4(\mathrm{~s})} \\
2 / 3 \mathrm{Fe}_{3} \mathrm{O}_{4(\mathrm{~s})}+1 / 6 \mathrm{O}_{2}+\mathrm{ZnO}_{(\mathrm{s})}=\mathrm{ZnFe}_{2} \mathrm{O}_{4(\mathrm{~s})}\end{array}$ \\
\hline 3 & $\begin{array}{l}\mathrm{Fe}_{(\mathrm{s})}+1 / 2 \mathrm{O}_{2(\mathrm{~g})}=\mathrm{FeO}_{(\mathrm{s})} \\
2 \mathrm{FeO}_{(\mathrm{s})}+1 / 2 \mathrm{O}_{2}+\mathrm{ZnO}_{(\mathrm{s})}=\mathrm{ZnFe}_{2} \mathrm{O}_{4(\mathrm{~s})}\end{array}$ \\
\hline
\end{tabular}

Consideration of the thermodynamics of the oxidation of the BOS filter cake was carried out using FactSage 7.0, using the FactPS and FTOxide databases [17]. The simple Fe-Zn-O system is represented in Figure 6 by a $\log \left(\mathrm{pO}_{2}\right)$ - $\mathrm{T}$ phase diagram for 16.7 mass $\% \mathrm{ZnO}$ in the BOS filter cake (Table 1). For the conditions considered in Stage $2\left(\log \left(\mathrm{pO}_{2}\right)=-0.678,120<\mathrm{T}<600^{\circ} \mathrm{C}\right)$, the stable phases are hematite and spinel. The composition of the spinel phase under these conditions was also examined, again using FactSage, and was found to be close to that of stoichiometric zinc ferrite $\left(\mathrm{ZnFe}_{2} \mathrm{O}_{4}\right)$. Additionally, it is known that wüstite is not stable below temperatures of $570^{\circ} \mathrm{C}$ [18]. This rules out Reaction Scheme 3 as reaction 8 is not thermodynamically favoured for most of the temperature range considered for Stage 2. The results from the thermodynamic modelling strongly support Reaction Scheme 1 (forming both hematite and zinc ferrite), while ruling out scheme 3.

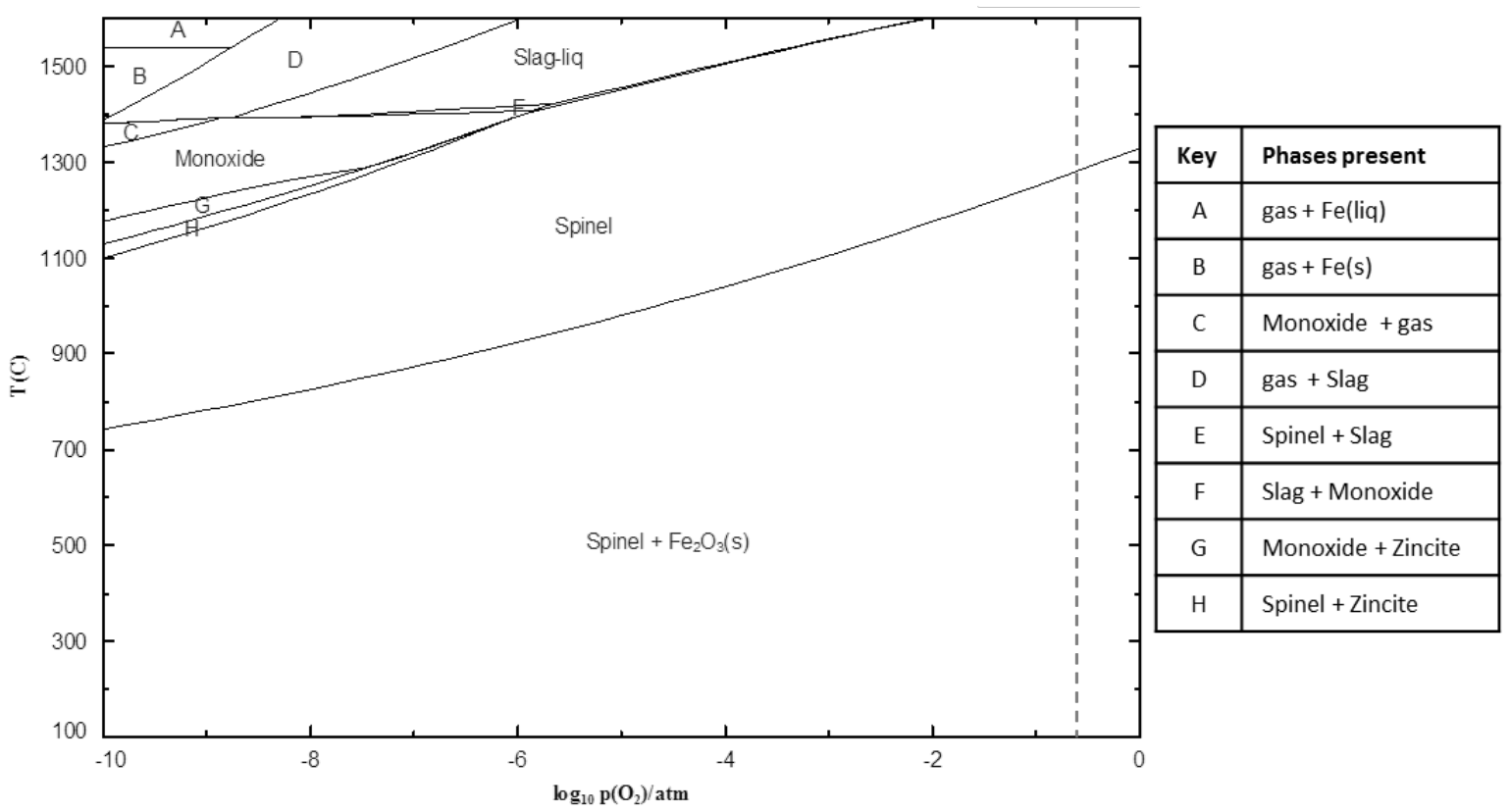

Figure 6. Thermodynamic stability diagram for the iron-zinc-oxygen system for a ZnO content of $16.7 \%$ (taken from the XRF results, Table 1), as calculated using FactSage [17].

Large-scale TGA samples were fast cooled from temperatures that corresponded to different stages. These were characterised to investigate the phases and morphology present at different stages. A distinctive shrinking core 
behaviour was present in the fast cooled samples, with different phases and different morphologies found in the outer layer and inner core, as described later when describing the bonding between particles. A typical example of this shrinking core is given in Figure 7 and the XRD patterns of each fast cooled sample are given in Figure 8. For the samples fast cooled from each temperature, XRD was performed on the whole sample, ground into a powder. It can be seen in Figure 8 that hematite and a spinel phase (either magnetite, zinc ferrite or a solid solution of the two) were formed at all temperatures, with their proportions increasing with increasing temperature. The phase analysis shows that the most likely phases being formed in Stage 2 were hematite and zinc ferrite, which strongly supports Reaction Scheme 1.

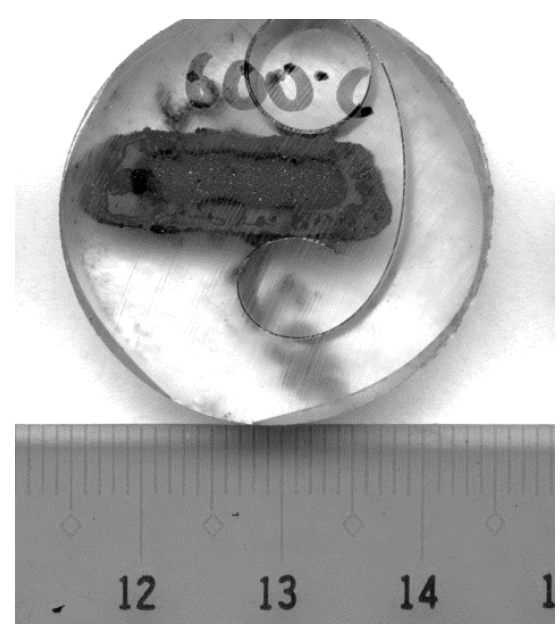

Figure 7. Typical example of a fast cooled sample (from $600^{\circ} \mathrm{C}$ ) showing the shrinking core behaviour. 


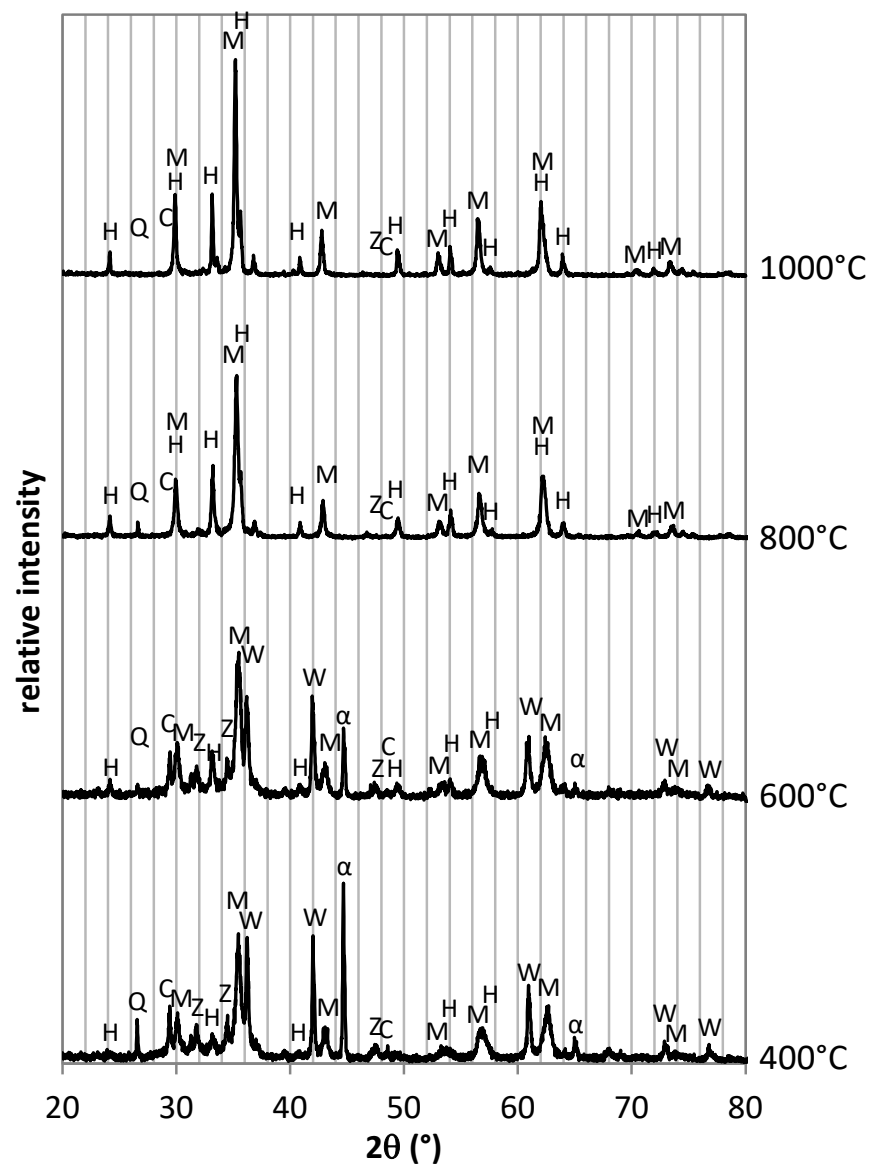

Figure 8. XRD patterns of BOS filter cake samples fast cooled from different temperatures. Phase key: $\alpha-$ ferrite; $\mathrm{W}$ - wüstite; $\mathrm{M}$ - magnetite-zinc ferrite (could be either or a solid solution of the two); $\mathrm{H}$ - hematite; $\mathrm{C}$ calcite; Q - quartz; Z - zincite.

The measurement of the enthalpy of the peak associated with Stage 2 was used to compare with the predicted enthalpy for each of the reaction schemes presented in Table 2. The energy (enthalpy) associated with the main oxidation peak in Figure 5 was measured from the area under the DSC curves, using a Bézier baseline [19].

The predicted enthalpies were calculated using data from FactSage [17] taking into account the initial composition of the sample and the measured weight change during the reaction. The proportions of wüstite, metallic iron and $\mathrm{ZnO}$ in the initial BOS filter cake samples were used in the prediction of the reaction enthalpy. The measured weight change that corresponded to the DSC peak was used to determine the amount of the BOS filter cake that reacted.

The comparison between the predicted and measured enthalpies for each reaction scheme is given in Table 3 . Using the enthalpy values in Table 3 , an average root mean square (RMS) difference of $<2 \%$ was reported as a 'good' match between the enthalpies. Differences between the enthalpies in the range of 2 and $4 \%$ were reported as 'moderate' matches, while a difference $>4 \%$ was reported as a 'poor' match. While a match between a measured enthalpy by DSC and the reported or calculated enthalpy of < 5\% could be argued as a reasonable match, the terms 'good', 'moderate' and 'poor' have been used here to describe the relative differences between the reaction schemes. 
The heating rate did not have any effect on the measured enthalpies. While the values in Table 3 show some variation, this was mainly due to small changes in the sample mass. When the enthalpy is normalised using the initial weight of the sample, all of the measured enthalpies were $-1.2 \mathrm{~J} / \mathrm{mg}$.

While many of the reaction schemes had reasonable matches between the measured and predicted enthalpies, the best match was for Scheme 1, dealing with the formation of hematite and zinc ferrite. This result agrees well with the results from both the characterisation of the reacted BOS filter cake samples and the thermodynamic modelling.

Table 3. Comparison between the measured and predicted enthalpies in Stage 2 in the self-sintering process.

\begin{tabular}{|c|c|c|c|c|c|c|c|}
\hline \multirow[t]{3}{*}{ Scheme } & Reactions & heating rate & $5^{\circ} \mathrm{C} / \mathrm{min}$ & $10^{\circ} \mathrm{C} / \mathrm{min}$ & $\begin{array}{l}10^{\circ} \mathrm{C} / \mathrm{min} \\
\text { repeat }\end{array}$ & $20^{\circ} \mathrm{C} / \mathrm{min}$ & \multirow[t]{3}{*}{$\begin{array}{l}\text { Average } \\
\text { RMS } \\
\text { difference }\end{array}$} \\
\hline & & $\triangle \mathrm{FWC}$ & 0.0691 & 0.0677 & 0.0665 & 0.0699 & \\
\hline & & \begin{tabular}{|c|}
$\Delta \mathrm{H}$ (measured) \\
$(\mathrm{J})$
\end{tabular} & -115 & -116 & -119 & -104 & \\
\hline \multirow[t]{2}{*}{1} & \multirow{2}{*}{$\begin{array}{l}\mathrm{Fe}_{(\mathrm{s})}+3 / 4 \mathrm{O}_{2(\mathrm{~g})}=1 / 2 \mathrm{Fe}_{2} \mathrm{O}_{3(\mathrm{~s})} \\
\mathrm{FeO}_{(\mathrm{s})}+\mathrm{O}_{2(\mathrm{~g})}=1 / 2 \mathrm{Fe}_{2} \mathrm{O}_{3}(\mathrm{~s}) \\
\mathrm{Fe}_{2} \mathrm{O}_{3}+\mathrm{ZnO}_{(\mathrm{s})}=\mathrm{ZnFe}_{2} \mathrm{O}_{4(\mathrm{~s})}\end{array}$} & $\Delta \mathrm{H}$ (data) $(\mathrm{J})$ & -114 & -115 & -121 & -103 & \multirow[b]{2}{*}{1.1} \\
\hline & & \%difference & 0.7 & 0.8 & -2.1 & 0.6 & \\
\hline \multirow[t]{2}{*}{2} & \multirow{2}{*}{$\begin{array}{l}\mathrm{Fe}_{(\mathrm{s})}+2 / 3 \mathrm{O}_{2(\mathrm{~g})}=1 / 3 \mathrm{Fe}_{3} \mathrm{O}_{4(\mathrm{~s})} \\
\mathrm{FeO}_{(\mathrm{s})}+1 / 6 \mathrm{O}_{2(\mathrm{~g})}=1 / 3 \mathrm{Fe}_{3} \mathrm{O}_{4(\mathrm{~s})} \\
2 / 3 \mathrm{Fe}_{3} \mathrm{O}_{4(\mathrm{~s})}+1 / 6 \mathrm{O}_{2}+\mathrm{ZnO}_{(\mathrm{s})}=\mathrm{ZnFe}_{2} \mathrm{O}_{4(\mathrm{~s})}\end{array}$} & $\Delta \mathrm{H}$ (data) $(\mathrm{J})$ & -116 & -117 & -124 & -105 & \multirow[b]{2}{*}{1.8} \\
\hline & & \%difference & -1.1 & -1.0 & -4.0 & -1.0 & \\
\hline 3 & $\begin{array}{l}\mathrm{Fe}_{(\mathrm{s})}+1 / 2 \mathrm{O}_{2(\mathrm{~g})}=\mathrm{FeO}_{(\mathrm{s})} \\
2 \mathrm{FeO}_{(\mathrm{s})}+1 / 2 \mathrm{O}_{2}+\mathrm{ZnO}_{(\mathrm{s})}=\mathrm{ZnFe}_{2} \mathrm{O}_{4(\mathrm{~s})}\end{array}$ & $\Delta \mathrm{H}($ data $)(\mathrm{J})$ & -119 & -121 & -127 & -108 & 4.5 \\
\hline
\end{tabular}

The summary of all of these different approaches to identifying which reactions occurred in Stage 2 was given in Table 4. Each of the approaches, phase characterisation, thermodynamic modelling and enthalpy measurement, led to the same finding, that Stage 2 represents the full oxidation of the BOS filter cake to hematite and zinc ferrite (Scheme 1). The different approaches used all gave similar answers, which provides confidence in the findings.

Table 4. Summary of the findings of the analysis of different reaction schemes for Stage 2 in the self-sintering process.

\begin{tabular}{|c|c|c|c|c|}
\hline Scheme & Equations & Thermodynamics & XRD & $\Delta \mathrm{H}$ fit \\
\hline 1 & $\begin{array}{l}\mathrm{Fe}_{(\mathrm{s})}+3 / 4 \mathrm{O}_{2(\mathrm{~g})}=1 / 2 \mathrm{Fe}_{2} \mathrm{O}_{3(\mathrm{~s})} \\
\mathrm{FeO}_{(\mathrm{s})}+\mathrm{O}_{2(\mathrm{~g})}=1 / 2 \mathrm{Fe}_{2} \mathrm{O}_{3}(\mathrm{~s}) \\
\mathrm{Fe}_{2} \mathrm{O}_{3}+\mathrm{ZnO}_{(\mathrm{s})}=\mathrm{ZnFe}_{2} \mathrm{O}_{4(\mathrm{~s})}\end{array}$ & Possible reactions & Good match & Good \\
\hline 2 & $\begin{array}{l}\mathrm{Fe}(\mathrm{s})+2 / 3 \mathrm{O}_{2(\mathrm{~g})}=1 / 3 \mathrm{Fe}_{3} \mathrm{O}_{4(\mathrm{~s})} \\
\mathrm{FeO}_{(\mathrm{s})}+1 / 6 \mathrm{O}_{2(\mathrm{~g})}=1 / 3 \mathrm{Fe}_{3} \mathrm{O}_{4(\mathrm{~s})} \\
2 / 3 \mathrm{Fe}_{3} \mathrm{O}_{4(\mathrm{~s})}+1 / 6 \mathrm{O}_{2}+\mathrm{ZnO}_{(\mathrm{s})}= \\
\mathrm{ZnFe}_{2} \mathrm{O}_{4(\mathrm{~s})}\end{array}$ & Possible reactions & Missing hematite & Good \\
\hline 3 & $\begin{array}{l}\mathrm{Fe}(\mathrm{s})+1 / 2 \mathrm{O}_{2(\mathrm{~g})}=\mathrm{FeO}_{(\mathrm{s})} \\
2 \mathrm{FeO}_{(\mathrm{s})}+1 / 2 \mathrm{O}_{2}+\mathrm{ZnO}_{(\mathrm{s})}=\mathrm{ZnFe}_{2} \mathrm{O}_{4(\mathrm{~s})}\end{array}$ & $\begin{array}{l}\text { Should not be } \\
\text { possible at }<570^{\circ} \mathrm{C}\end{array}$ & Missing hematite & Poor \\
\hline
\end{tabular}


Stage 3.

Calcination of dolomite at $\sim 600-620^{\circ} \mathrm{C}<\mathrm{T}<770^{\circ} \mathrm{C}$. This was observed by a decrease in sample weight and a small endothermic peak. This mass loss was likely caused by calcination of one of the flux phases in the BOS filter cake. There are several flux phases that were expected to be found within the BOS filter cake. These include burnt and unburnt lime ( $\mathrm{CaO}$ and $\mathrm{CaCO}_{3}$, respectively), burnt dolomite (considered as a mixture of $\mathrm{CaO}$ and $\mathrm{MgO})$, and unburnt dolomite $\left(\mathrm{CaMg}\left(\mathrm{CO}_{3}\right)_{2}\right)$, all of which may be entrained with the off-gas in the BOS [5].

The thermodynamics of calcination of several fluxes was considered through the Gibbs free energy $\left(\Delta \mathrm{G}^{\circ}\right)$ of simple reactions, given in Equations 10-14, using the FactSage [17] database. If $\Delta \mathrm{G}^{\circ}<0 \mathrm{~kJ} / \mathrm{mol}$ then the reaction was considered possible at the temperature considered. Burnt fluxes would be expected to have hydrated during the wet scrubbing and separation processes and were considered as $\mathrm{Ca}(\mathrm{OH})_{2}$ and $\mathrm{Mg}(\mathrm{OH})_{2}$. The temperatures at which different calcining reactions become thermodynamically possible are given in Table 5.

$$
\begin{aligned}
& \mathrm{CaCO}_{3(\mathrm{~s})}=\mathrm{CaO}_{(\mathrm{s})}+\mathrm{CO}_{2(\mathrm{~g})} \\
& \mathrm{Ca}(\mathrm{OH})_{2(\mathrm{~s})}=\mathrm{CaO}_{(\mathrm{s})}+\mathrm{H}_{2} \mathrm{O}_{(\mathrm{g})} \\
& \mathrm{CaMg}\left(\mathrm{CO}_{3}\right)_{2(\mathrm{~s})}=\mathrm{CaO}_{(\mathrm{s})}+\mathrm{MgO}_{(\mathrm{s})}+2 \mathrm{CO}_{2(\mathrm{~g})} \\
& \mathrm{CaMg}\left(\mathrm{CO}_{3}\right)_{2(\mathrm{~s})}=\mathrm{CaCO}_{3(\mathrm{~s})}+\mathrm{MgO}_{(\mathrm{s})}+\mathrm{CO}_{2(\mathrm{~g})} \\
& \mathrm{Mg}(\mathrm{OH})_{2(\mathrm{~s})}=\mathrm{MgO}_{(\mathrm{s})}+\mathrm{H}_{2} \mathrm{O}_{(\mathrm{g})}
\end{aligned}
$$

Table 5. Temperature at which $\Delta \mathrm{G}^{\circ}=0 \mathrm{~kJ} / \mathrm{mol}$ for the calcination of different fluxes.

\begin{tabular}{|l|l|l|}
\hline Flux & Reaction & $\mathbf{T}\left(\mathbf{\Delta \mathbf { G } ^ { \circ }}=\mathbf{0}\right)$ \\
\hline Limestone, $\mathrm{CaCO}_{3}$ & $\mathrm{CaCO}_{3(\mathrm{~s})}=\mathrm{CaO}_{(\mathrm{s})}+\mathrm{CO}_{2(\mathrm{~g})}$ & $894^{\circ} \mathrm{C}$ \\
\hline Hydrated lime, $\mathrm{Ca}(\mathrm{OH})_{2}$ & $\mathrm{Ca}(\mathrm{OH})_{2(\mathrm{~s})}=\mathrm{CaO}_{(\mathrm{s})}+\mathrm{H}_{2} \mathrm{O}_{(\mathrm{g})}$ & $525^{\circ} \mathrm{C}$ \\
\hline Dolomite, $\mathrm{CaMg}\left(\mathrm{CO}_{3}\right)_{2}$ & $\mathrm{CaMg}\left(\mathrm{CO}_{3}\right)_{2(\mathrm{~s})}=\mathrm{CaO}_{(\mathrm{s})}+\mathrm{MgO}_{(\mathrm{s})}+2 \mathrm{CO}_{2(\mathrm{~g})}$ & $643^{\circ} \mathrm{C}$ \\
\cline { 2 - 3 } & $\mathrm{CaMg}\left(\mathrm{CO}_{3}\right)_{2(\mathrm{~s})}=\mathrm{CaCO}_{3(\mathrm{~s})}+\mathrm{MgO}_{(\mathrm{s})}+\mathrm{CO}_{2(\mathrm{~g})}$ & $425^{\circ} \mathrm{C}$ \\
\hline Hydrated magnesia, $\mathrm{Mg}(\mathrm{OH})_{2}$ & $\mathrm{Mg}(\mathrm{OH})_{2(\mathrm{~s})}=\mathrm{MgO}_{(\mathrm{s})}+\mathrm{H}_{2} \mathrm{O}_{(\mathrm{g})}$ & $267^{\circ} \mathrm{C}$ \\
\hline
\end{tabular}

For the temperature range involved in Stage $3\left(600-770^{\circ} \mathrm{C}\right)$, calcination of unburnt dolomite, hydrated dolomite and hydrated lime (Equations 11-14) are thermodynamically possible, while the calcination of calcium carbonate (unburnt lime, Equation 10) is not. Hence, the mass loss and endothermic reactions associated with Stage 3 are likely to be the calcination of hydrated fluxes and unburnt dolomite.

Stage 4.

A very small weight gain at $\sim 730-770^{\circ} \mathrm{C}<\mathrm{T}<\sim 900^{\circ} \mathrm{C}$. It is possible that this may represent the final oxidation of the larger wüstite and metallic iron particles within the BOS filter cake.

Stage 5. 
A very small decrease in sample weight at $\mathrm{T}>900^{\circ} \mathrm{C}$, possibly caused by calcination of unburnt lime. Referring again to Table 5, the calcination of unburnt lime $\left(\mathrm{CaCO}_{3}\right.$, Equation 10) only becomes possible at temperatures above $894^{\circ} \mathrm{C}$. This temperature corresponds well with the temperature range for this stage, likely indicating that Stage 5 is the calcination of unburnt lime.

\section{Bonding in post-reaction samples}

The microstructures of the fast cooled, post-reaction samples were characterised by SEM-EDS. Due to the shrinking core type behaviour seen in the fast cooled samples (Figure 7), they were only examined in the outer product layer. Similarly to the self-sintered samples (Figure 3), at low magnifications, it was difficult to distinguish the reacted samples from the unreacted material.

At higher magnifications (Figure 9), again similar to the self-sintered samples, there was some evidence of bond formation in the quench samples. There was some evidence of bonding between the fine iron oxide particles even at $400^{\circ} \mathrm{C}$, with the level of bonding in the samples increasing with increasing temperature. The formation of bonds between the iron oxide particles at these relatively low temperatures is driven by the very fine particle size. This initial fine particle size gives a strong driving force towards minimising surface area, leading to agglomeration even at the temperatures studied.

It was also clear from the high magnification microscopy that the fluxes were playing little role in the development of the bonding between the fine iron oxide particles. Thus, it is likely that stages 3 and 5, described above, do not have a role in the self-sintering process. From the presence of the discrete flux particles in the microstructures (both Ca and Mg rich flux particles have been observed) in each of the fast cooled samples, the fluxes did not react with the iron or iron oxides during the self-sintering process. Consequently, $\mathrm{CaO}, \mathrm{MgO}$ and $\mathrm{SiO}_{2}$ were not considered in any of the reaction schemes given in Table 2. While the formation of calcium ferrites could be expected [20,21], they were not observed in these samples, either by XRD or in the microstructures. While the formation of these phases may be kinetically limited due the short durations of these experiments, the fine nature of both the iron oxides and fluxes and the associated high expected reactivity would seemingly contradict this. The lack of interaction between the iron oxides and fluxes requires further study.

In order to understand what temperatures and conditions are required for producing self-sintered filter cake that has suitable strength for handling and transport for recycling, the microstructures of the fast cooled samples (Figure 9) can be compared with those found in the self-sintered samples taken from the stockpiles (Figure 3). All of the fast cooled samples appear to have more bonding than the self-sintered sample that was not suitable for recycling. However, the self-sintered sample suitable for recycling had more developed bonding than that seen in the $400^{\circ} \mathrm{C}$ fast cooled sample. It appears as though heating the BOS filter cake to temperatures above $600^{\circ} \mathrm{C}$ through the self-sintering process is required to give the BOS filter cake sufficient strength for transport and recycling in the BOS. 


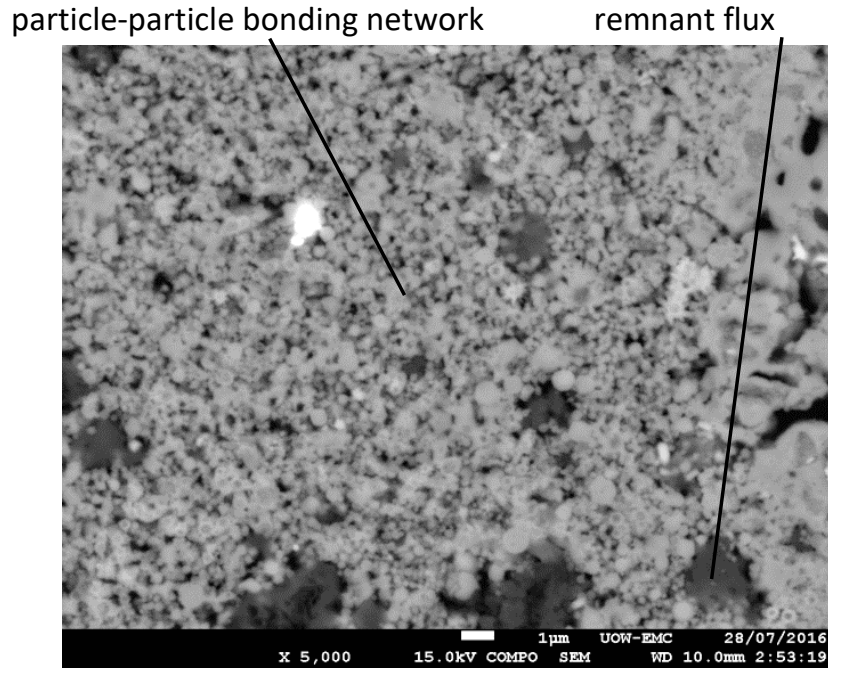

(a) remnant flux particle-particle bonding network

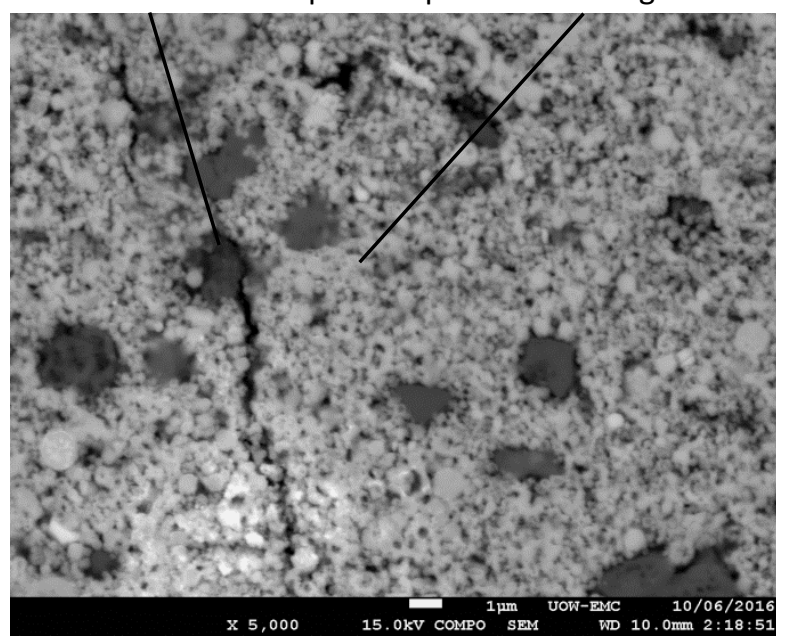

(b)

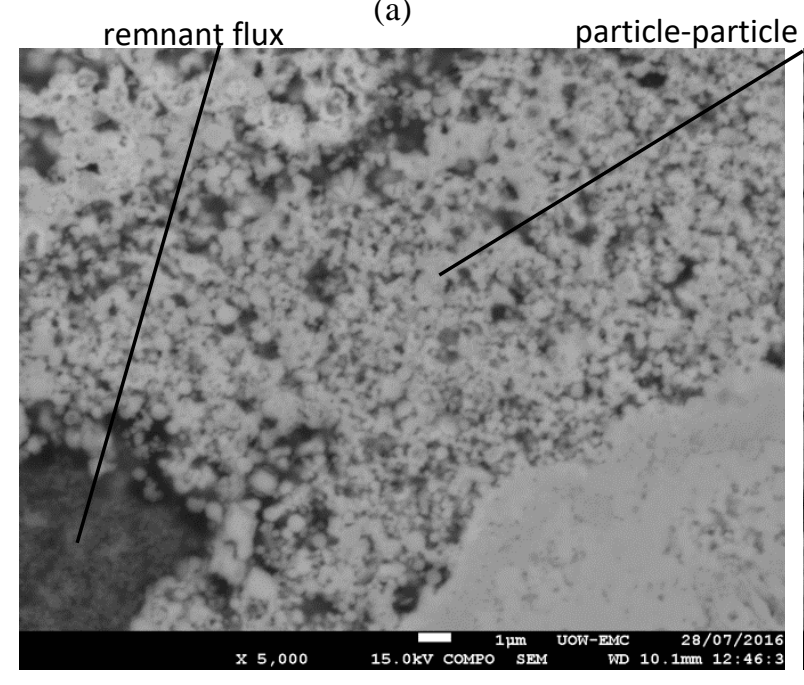

(c)

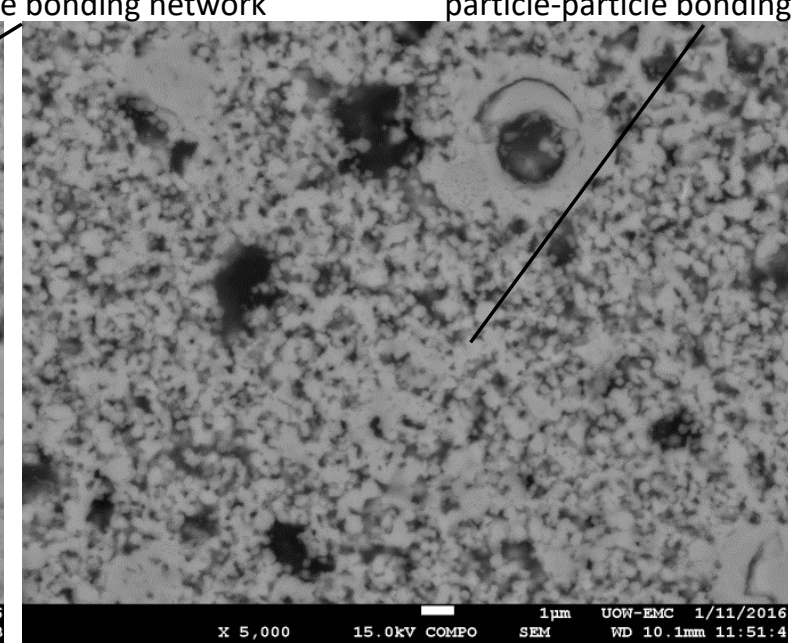

(d)

Figure 9. High magnification SEM images of the outer product layer of BOS filter cake samples fast cooled from (a) $400^{\circ} \mathrm{C}$; (b) $600^{\circ} \mathrm{C}$; (c) $800^{\circ} \mathrm{C}$; and (d) $1000^{\circ} \mathrm{C}$ in air. The scale bars are $1 \mu \mathrm{m}$.

The self-sintering process can be described as a thermal sintering of fine iron oxide particles at elevated temperature. It is likely that the release of energy and increase in temperature that accompanied the exothermic reactions in Stage 2 played a larger role in the formation of the bonds than the formation of new phases from the same reactions.

\section{Conclusions}

The self-sintering process of BOS filter cake has been studied by examining its oxidation from 100 to $1000^{\circ} \mathrm{C}$, with an emphasis on improving the recyclability of the BOS filter cake to the BOS, replacing iron ore as coolant and serving as a cheap iron source. The aim of the study was to gain an understanding of what was occurring during the self-sintering process, in terms of what reactions occurred, as well as how bonding developed in the filter cake during self-sintering.

Unreacted BOS filter cake from the BlueScope steelworks was characterised by SEM and XRD, with the reactivity in air during heating measured by TGA and TGA-DSC. These samples were compared to self-sintered BOS filter 
cake from the plant stockpiles that was also characterised by XRD and SEM. The BOS filter cake showed a characteristic behaviour during heating in air, consisting of largely sequential drying, oxidation and calcination events.

The BOS filter cake showed high reactivity with air, even at low temperatures, asserted to be wholly caused by very small particles of metallic iron and wüstite. The oxidation of the BOS filter cake started when the filter cake was dry and the temperature approximately $120^{\circ} \mathrm{C}$, and was largely complete by $500-600^{\circ} \mathrm{C}$. Phase analysis, thermodynamic modelling and measurement of the enthalpy of reaction were all used to propose the likely reactions occurring during self-sintering. These assessment approaches all gave similar findings. The likely reactions in the $120-600^{\circ} \mathrm{C}$ temperature range were found to be the oxidation of metallic iron and wüstite to hematite and zinc ferrite. These exothermic oxidation reactions at low temperatures are believed to provide the energy required to heat the stockpiles and drive self-sintering.

Strength required for recycling the BOS filter cake was from a network of particle-particle bonds that formed between the very fine iron oxide particles in the matrix during oxidation at elevated temperatures. Exposure of the BOS filter cake to temperatures between $600-800^{\circ} \mathrm{C}$ under oxidising conditions is likely sufficient to form adequately strong material for transport and recycling in the BOS. Fluxes played little role in the development of the bonding within the filter cake. It is likely that through the improved understanding of the self-sintering process, enhancements to the process can be achieved that will lead to a greater proportion of recyclable material.

The recycling of the BOS filter cake back to the BOS would be enhanced through an increased amount of selfsintering, which increases the strength and increases the yield of $>4 \mathrm{~mm}$ material. Self-sintering would be enhanced by ensuring that the moisture content of the BOS filter cake is kept low during de-watering. Heating the stockpiled BOS filter cake to temperatures above $120^{\circ} \mathrm{C}$ would ensure initiation of the self-sintering reactions.

\section{Conflict of interest}

On behalf of all authors, the corresponding author states that there is no conflict of interest.

\section{References}

1. Nyirenda RL (1991) The processing of steelmaking flue-dust: A review. Minerals Eng 4: 1003-1025

2. Hleis D, Fernández-Olmo I, Ledoux F, Kfoury A, Courcot L, Desmonts T, Courcot D (2013) Chemical profile identification of fugitive and confined particle emissions from an integrated iron and steelmaking plant. J Hazardous Materials 250-251: 246-255

3. Ahmed HM, Persson A, Ökvist LS, Björkman B (2015) Reduction behaviour of self-reducing blends of inplant fines in inert atmosphere. ISIJ International 55: 2082-2089

4. Makkonen HT, Heino J, Laitila L, Hiltunen A, Pöyliö E, Härkki J (2002) Optimisation of steel plant recycling in Finland: dusts, scales and sludge. Resources, Conservation and Recycling 35: 77-84

5. $\quad$ Nedar L (1996) Dust formation in a BOF converter. Steel Research 67: 320-327 
6. Hayes P (1993) Process Principles in Minerals \& Materials Production. Hayes Publishing, Sherwood, QLD, Australia

7. Suetens T, Guo M, Van Acker K, Blanpain B (2015) Formation of the $\mathrm{ZnFe}_{2} \mathrm{O}_{4}$ phase in an electric arc furnace off-gas treatment system. J Hazardous Materials 287: 180-187

8. Suetens T, Guo M., Van Acker K, Blanpain B (2015) Gas-Solid Reaction Kinetics of $\mathrm{ZnFe}_{2} \mathrm{O}_{4}$ Formation from 907 to $1100^{\circ} \mathrm{C}$. J Physical Chemistry A 119: 4718-4722

9. Steer J, Grainger C, Griffiths A, Griffiths M, Heinrich T, Hopkins A (2014) Characterisation of BOS steelmaking dust and techniques for reducing zinc contamination. Ironmaking Steelmaking 41: 61-66

10. Kelebek S, Yörük S, Davis, B (2004) Characterisation of basic oxygen furnace dust and zinc removal by acid leaching. Minerals Engineering 17: 285-291

11. Longbottom RJ, Monaghan BJ, Zhang G, Chew SJ, Pinson DJ (2016) Characterisation of Steelplant ByProducts to Realise the Value of Fe and Zn. In:Proc. 7th European Coke and Ironmaking Congress, ASMET, Leoben, Austria, pp. 1017-1026

12. Longbottom RJ, Monaghan BJ, Zhang G, Chew SJ, Pinson DJ (2016) Characterisation and Resource Development of Steel Plant By-Product Streams. In: Chemeca 2016: Chemical Engineering - Regeneration, Recovery and Reinvention, RACI, Melbourne, pp. 352-362

13. Longbottom RJ, Monaghan BJ, Zhang G, Pinson DJ, Chew SJ (2019) Self-sintering of BOS Filter Cake for Improved Recyclability. ISIJ International 59: 432-441

14. Chun T, Zhu D (2015) New Process of Pellets-Metallized Sintering Process (PMSP) to Treat Zinc-Bearing Dust from Iron and Steel Company. Metallurgical and Materials Transactions B, 46B, 1-4

15. Hay SM, Rankin WJ (1994) Recovery of Iron and Zinc from Blast Furnace and Basic Oxygen Furnace Dusts: A Thermodynamic Evaluation. Minerals Engineering 7: 985-1001

16. Jaafar I, Griffiths AJ, Hopkins AC, Steer JM, Griffiths MH, Sapsford DJ (2011) An evaluation of chlorination for the removal of zinc from steelmaking dusts. Minerals Engineering 24: 1028-1030

17. Bale CW, Bélisle E, Chartrand P, Decterov S, Eriksson G, Gheribi A, Hack K, Jung I-H, Melancon J, Pelton, AD, Petersen S, Robelin C (2014) Recent Developments in FactSage Thermochemical Software and Databases. In: Mackey P, Grimsey E, Jones R, Brooks G (Eds) Celebrating the Megascale: Proceedings of the Extraction and Processing Division Symposium on Pyrometallurgy in Honor of David G.C. Robertson, TMS, Warrendale PA, pp 114-148

18. Muan A, Osborn EF (1965) Phase Equilibria Among Oxides in Steelmaking. Addison-Wesley Publishing, Reading, MA, US, pg 25 
19. Ahn YJ, Kim YS, Shin Y (2004), Approximation of circular arcs and offset curves by Bézier curves of high degree. J Computational and Applied Mathematics 167: 405-416

20. Wang Z, Pinson D, Chew S, Monaghan BJ, Pownceby MI, Webster NA, Rogers H, Zhang G (2016), Effects of Sintering Materials and Gas Conditions on Formation of Silico-Ferrites of Calcium and Aluminium during Iron Ore Sintering. ISIJ International 56: 1138-1147

21. Webster NAS, Pownceby MI, Madesn IC, Kimpton JA (2012), Silico-Ferrite of Calcium and Aluminium (SFCA) Iron Ore Sinter Bonding Phases: New Insights Into Their Formation During Heating and Cooling. Metallurgical and Materials Transactions B 43B: 1344-1357 